Frederico, I.B.; Bruhns, H.T. As experiências no cerrado: uma reflexão das possibilidades do Ecoturismo. Anais do VIII Congresso Nacional de Ecoturismo e do IV Encontro Interdisciplinar de Ecoturismo em Unidades de Conservação. Revista Brasileira de Ecoturismo, São Paulo, v.4, n.4, 2011 , p. 548.

\title{
AS EXPERIÊNCIAS NO CERRADO: UMA REFLEXÃO DAS POSSIBILIDADES DO ECOTURISMO
}

\author{
Isabela Barbosa Frederico*, Heloísa Turini Bruhns* \\ *Universidade Estadual de Campinas \\ E-mails: isabf_tur@yahoo.com.br, luabola@uol.com.br
}

Este estudo se trata de um projeto de mestrado, em curso, do Departamento de geografia da Unicamp, e tem como objetivo explorar o universo das relações que se dão em torno do homem e da natureza ao longo de práticas de ecoturismo. O espaço natural contemplado na pesquisa é o cerrado, tendo em vista a importância deste bioma no território nacional e as conseqüentes ameaças que o mesmo vem enfrentando ao ser esquecido no imaginário ocidental das grandes florestas. O cerrado é considerado a savana mais rica em biodiversidade mundial. No Brasil, em área total, se configura como o segundo maior bioma atrás apenas da Floresta Amazônica. Ao longo de sua fisionomia vegetal bastante heterogênea encontra-se um número considerável de espécies endêmicas e ameaçadas de extinção. Apesar desse contexto, o total de unidades de conservação que protegem essas áreas é inexpressivo, evidenciando a necessidade de atividades que busquem uma sensibilização do ser humano em relação à importância de sua preservação. O ecoturismo pode ser destacado como ferramenta de intervenção no patrimônio natural através da dimensão subjetiva e experiencial do ser humano. A busca pela natureza hoje, enquanto fenômeno social contemporâneo deve ultrapassar a dicotomia entre cultura e natureza apontando novas possibilidades de ação e conservação. É um consenso nos debates ambientais a importância da mudança de percepção que contemple não apenas o olhar racional do espaço, mas também a dimensão emotiva do ser humano. Assim, o presente estudo pretende refletir sobre a complexidade dessa experiência enfocando a relação entre o planejamento ecoturístico e a educação ambiental no cerrado. A área de estudo contemplada será a RPPN "Serra do Caraça" em Minas Gerais. A reserva, que possui uma visitação turística expressiva, possibilita a análise de três situações interessantes: a iniciativa de conservação em uma propriedade particular mantida desde 1819 pela Missão dos Lazaristas; o ecoturismo como alternativa para a conservação e a relação entre a cultura e o meio ambiente, através da presença de um patrimônio histórico local e uma tradição que se tornou ícone da reserva, qual seja, o ritual da alimentação aos lobos guarás (espécie de mamífero endêmica do cerrado) que ocorre diariamente após o jantar na escadaria da igreja localizada na área. A pesquisa se dará pela vertente qualitativa, uma vez que sua flexibilidade permite o ensejo de compreender um fenômeno social e suas significações, e se utilizará da observação participante e entrevistas semi-estruturadas com os atores envolvidos com o ecoturismo. Essa escolha está calcada na potencialidade que a observação traz ao se apreender o fenômeno tal qual ele ocorre e pela entrevista ser favorável, através da fala, da obtenção de dados que envolvam sensibilidade e experiência. A amostragem se dará segundo a necessidade que o estudo vá estabelecendo em relação à saturação dos dados relevantes para alcançar os objetivos propostos. Desta forma, o presente trabalho pretende contribuir com as reflexões sobre a experiência corpo-natureza em ambientes de cerrado como alternativas para fomentar os projetos de educação ambiental e planejamento ecoturístico envolvendo unidades de conservação.

Palavras chave: Ecoturismo; Cerrado; Experiência. 